\title{
Stability of cassava flour-based food bars
}

\author{
Estabilidade de alimento em barra à base de farinha de mandioca
}

\author{
Érica Caroline da SILVA ${ }^{1 *}$, Viviane dos Santos SOBRINHO ${ }^{1}$, Marney Pascoli CEREDA ${ }^{1}$
}

\begin{abstract}
The consumption of Brazilian cassava has been reduced due to a lack of adjustment to the modern lifestyle. To reverse this trend, new products could be developed specifically targeted to high-value niche markets. Cereal bars stand out as fast food high in nutritional value. A bar formula mimicking cereal bars was prepared using a mixture of Brazilian cassava flour, hydrogenated vegetable fat, dried bananas, ground cashew nuts, and glucose syrup. After being pressed, the bars were dried for 1 hour at $65^{\circ} \mathrm{C}$, packaged in films, and stored under ambient conditions. Its stability was continuously monitored for 210 days in order to ensure its safety and enable its introduction to the market. Texture loss was observed in the packed bars after 90 days of storage, but the sensory characteristics allowed the testers to perceive this tendency after only 30 days of storage. However, chemical, physical, and microbial analyses confirmed that the bars were safe for consumption for 180 days. The results showed that a $45 \mathrm{~g}$ cassava flour-based bar enriched with nuts and dried fruits can meet $6 \%$ of the recommended daily fiber intake with a caloric value between that of the common cereal bar and that of an energy bar. Adapting the formula with ingredients (fruits, nuts) from different regions of Brazil may add value to this traditional product as a fast food.
\end{abstract}

Keywords: stability; fast food; market; microbiology.

\section{Resumo}

A farinha de mandioca apresenta redução de consumo por não se adequar ao estilo de vida moderno. Para inverter esta tendência, novos produtos poderão ser desenvolvidos e direcionados a mercados valorizados. As barras de cereais destacam-se como fast food de bom perfil nutricional. Uma fórmula foi usada para mimetizar as barras de cereais, usando uma mistura de farinha de mandioca, gordura vegetal, bananas secas, castanha de caju e xarope de glicose. As barras prensadas foram secas por 1 hora a $65^{\circ} \mathrm{C}$, embaladas em filmes e armazenadas em condição ambiente. A estabilidade do produto foi acompanhada durante 180 dias, com o intuito de garantir um alimento seguro e possibilitar sua entrada no mercado. As barras perderam textura dentro das embalagens após 90 dias, mas as características organolépticas permitiram aos provadores perceberem essa tendência a partir de 30 dias. As análises fisico-químicas e microbianas confirmaram que as barras permaneceram como alimento seguro durante 180 dias. Os resultados mostraram que $45 \mathrm{~g}$ de barras de farinha de mandioca enriquecidas com castanhas e frutas secas podem satisfazer $6 \%$ da ingestão diária de fibras, com valor calórico intermediário entre barras comuns e as do tipo energéticas. A adaptação da formulação com ingredientes locais (frutas, castanhas) de diferentes regiões brasileiras poderá proporcionar a valorização deste produto tradicional como alimento rápido.

Palavras-chave: estabilidade; alimentação rápida; mercado; microbiologia.

\section{Introduction}

Cereal bars stands out among fast foods due to their balanced nutritional content and convenience. On the other hand cassava flour consumption, despite its importance as a traditional food in Brazil, has significantly reduced because its preparation does not suit modern lifestyles.

Cereal bars are made from a compressed mixture of cereals and dried fruit. Generally, the glucose syrup is the aggregator element of the bar ingredientes providing rapid energy absorption. On other hand, since cereal is a complex carbohydrate, the starch provides slower energy liberation, which can be absorbed for a longer period of time. The most commonly used ingredients in cereal bars are oat, wheat or rice, and soy. A cereal bar is considered a practical choice for a quick meal due to its high nutritional value (DEGASPARI; BLINDER; MOTTIN, 2008).
Cereal bars may be considered a good source of carbohydrate and may promote the recovery of energy following exercises when used as a food supplement or as "portable nutrition" (BRITO, 2005). Therefore, the association between cereal bars and health food is a well-documented tendency in in the food sector (GUTKOSKI, 2007).

Dutcosky et al. (2006) reported increased consumption of cereal bars associated with the change of lifestyles and the need of fast meals and snacks. Consumers have easily accepted cereal bars because they are considered to be nutritionally balanced high-fiber snacks and also because they have an adequate balance between calories, fat, protein, vitamins, minerals, fiber and whole grains are beneficial to consumer health (RYLAND et al., 2010).

Received 22/3/2012

Accepted 12/12/2012 (005600)

${ }^{1}$ Centro de Tecnologia e Análise do Agronegócio - CeTeAgro, Instituto São Vicente, Universidade Católica Dom Bosco - UCDB, Av. Tamandaré, 8000, Jardim Seminários, CEP 79117-900, Campo Grande, MS, Brasil,e-mail: ericacarols@yahoo.com.br

${ }^{*}$ Corresponding author

DOI: http://dx.doi.org/10.1590/S0101-20612013005000025 
Pehanich (2003) reports that cereal bars may be considered as a fast food that suits the diet foods market due to their nutrition and energy content, especially for women, weekend athletes, and professional athletes. The bars are presented in the market as a healthy alternative to the most frequently consumed chocolate bars in Brazil by sports enthusiasts (FREITAS; MORETTI, 2006).

From a nutritional point of view, the bars may be classified into four types: fibrous, energy, diet (light), and protein bars. Fibrous bars have a high fiber and glucose content with an energy value near $100 \mathrm{kcal}$ per unit. Diet bars have only 65 calories, are sugar free, and are an option for diabetic consumers. The bars with $280 \mathrm{kcal}$ provide easily absorbed energy because they contain less fiber and have a high caloric value. They are recommended for energy replacement following strenuous physical activity. Finally, protein bars with $200 \mathrm{kcal}$ have approximately $17 \mathrm{~g}$ of protein per unit as well as a lower fat content (DEGASPARI; BLINDER; MOTTIN, 2008).

Freitas and Moretti (2006) developed bar formulas with several types of cereal. The cereal bar made with banana had a profile of $60.97 \%$ carbohydrates, $10.71 \%$ moisture, $15.31 \%$ protein, $5.65 \%$ fat, $5.17 \%$ total fiber, and $2.20 \%$ ash. Brito et al. (2004) evaluated homemade cereal bars and found the following composition: $80.85 \%$ carbohydrates, $7.63 \%$ moisture, $6.27 \%$ protein, $3.44 \%$ fiber, $1.13 \%$ ash, and $0.68 \%$ lipids. The same authors point out that the bars may show a different nutritional value according to the ingredients used in the formula.

The consumption of cereal bars increased $11 \%$ globally in 2007, and it represents a market of about US\$ 4 billion leading to an increase in the variety of cereal bars, labels, and different ingredients in order to attract consumers. Despite a noticeable increase in consumption, Mahanna, Moskowitz and Lee (2009) believe that the research on market expectations and consumption is still incomplete.

This sector is also considered very poor in terms of availability of raw materials. Besides cereal products, there are few new options offered to consumers. Brazil, with its diverse agricultural production, could offer customized regional formulas for the production of cereal bars. Among the possible raw materials with compatible characteristics, Brazilian cassava flour, considered to be a Brazilian food with strong cultural characteristics, stands out as a possibility.

Cassava consumption has strong culinary tradition in Brazil. In addition to its use in fried or special dishes, cassava is also processed for flour. Several types of cassava flour can be found throughout the country (CEREDA, 2001). Despite its economic and social value, since it is the most popular cassava derivative, traditional Brazilian cassava flour consumption has declined in the last decade. The modernization of food habits is the major contributor to the decrease in consumption of cassava flour, as reported in the Household Budget Survey (HBS). In the period between 2008 and 2009, according to this publication, the average annual purchase per capita of cassava flour decreased from $4.9 \%$ to $3.9 \%$, but in the same time-period the consumption of processed foods increased (INSTITUTO..., 2011).
In Brazil, cassava flour has great economic and social importance, but its use is limited to traditional cuisine, which does not correspond to the modernization of the food sector (CEREDA; VILPOUX, 2003). Cassava flour is considered a caloric food due to its starch content. According to the food composition tables of Franco (2007), cassava flour may generate $350 \mathrm{kcal}$ per $100 \mathrm{~g}$. It also contains small amounts of protein, calcium, phosphorus, sodium, and potassium (DUARTE, 2008).

The chemical composition of cassava flour established in the literature corroborates that information. Souza et al. (2008) analyzed samples of homemade flour prepared with eight cassava varieties and concluded that the composition may vary depending on the variety. On average, the composition was $4.13 \%$ moisture, $0.63 \%$ ash, $1.37 \%$ fat, $0.60 \%$ protein, $1.83 \%$ crude fiber, and $91.41 \%$ of total carbohydrates. The information that the cassava fiber has a good nutritional quality compared to that of wheat bran as a standard fiber (LEONEL; CEREDA; ROAU, 1999) may provide a more favorable evaluation of cassava as a healthy food.

In the food industry, it is common to mix different ingredients with different nutritional and functional properties (GOMES et al., 2009). Mahanna, Moskowitz and Lee (2009) evaluated the parameters used by consumers when choosing cereal bars and found that consumers pay special attention to the caloric value and the type of ingredients used in the food. These authors confirmed that taste is the most important sensory attribute to consumers. Degaspari, Blinder and Mottin (2008) reported that the cereal bars commercialized in Brazil should include dried fruit such as banana as an ingredient in order to increase their acceptance. Cereal bars can also contain ingredients such as nuts that highlight the flavor and contribute to nutritional quality.

It is also possible to replace the cereals and their derivatives with gluten free ingredients enabling the bars to enter the specific food market for celiac disease patients, in addition to the regular fast food, nutrition, and energy food market. Celiac disease is a type of intolerance to gluten which affects between 0.5 and $1.0 \%$ of world's population (CASTRO-ANTUNES et al., 2010) and is characterized by partial or total atrophy of intestinal mucosa that results in nutrient malabsorption. The solution is the permanent withdrawal of gluten from the diet, which leads to the exclusion of cereals such as wheat, rye, barley, malt, and oats (SDEPANIAN; MORAL; FAGUNDES NETO, 2001). Cassava flour-based bars could also benefit consumers with celiac syndrome since they do not contain gluten.

According to Grizotto (2006), food product shelf life study consists of submitting several samples for a series of tests over a long enough period of time so as to establish its limit. Shelf life is a factor of paramount importance because it defines the storage period in which products with high initial quality remain safe for consumption (WRIGHT et al., 2004).

Freitas and Moretti (2006) reported changes during the storage of cereal bars made with a high protein and vitamin content (vitamin C and E). According to the authors, appearance, color, and overall impression were negatively affected, probably due to accelerated browning caused by vitamin $\mathrm{C}$ oxidation. 
Although the cereal bars were removed from their packaging immediately before the evaluation, these authors point out that the residual oxygen inside the package would be enough to catalyze the reaction. Other authors investigated the shelf life of cereal bars under ambient conditions for specific formulas. The storage of protein bars was evaluated for 50 days at $20^{\circ} \mathrm{C}$ (LOVEDAY et al., 2009) and granola bars for 28 days at $20^{\circ} \mathrm{C}$ (AIGSTER et al., 2011).

Among the advantages of cassava flour-based bars is the modernization and expansion of cassava flour market since the bars provide a nutritionally balanced food by the addition of dried fruit and nuts.

The objective of the present study was to add value to cassava flour as food by the development of a new product that is more adjusted to the modern lifestyle while maintaining the characteristics of this product. Shelf life was determined by monthly physical, chemical, sensory, and microbiology analyses of cassava flour-based bars packed in polyester-aluminumpolyethylene films and stored under ambient conditions.

\section{Materials and methods}

\subsection{Material}

The formula used in this study has been developed in a previous research by the same authors with the following ingredients: raw cassava flour (29\%), dehydrated banana (20\%), ground cashew nuts (23\%), commercial glucose syrup (26\%), and hydrogenated vegetable fat $(2 \%)$. The dehydrated banana was obtained from osmotic dehydration process followed by complementary oven drying, as described by Gomes, Vilpoux and Cereda (2007). All ingredients were used maintaining their characteristic moisture content.

\subsection{Preparation of bars}

All bars were prepared in a single batch with enough formulation to yield 12 bars. With this formulation, the bars could be mechanically pressed $\left(200 \mathrm{Kgf} / \mathrm{m}^{2}\right)$ in appropriate aluminum molds ( $10 \mathrm{~cm}$ long, $3 \mathrm{~cm}$ wide and $1 \mathrm{~cm}$ thick). The bars were then partially dried for about 1 hour at $65^{\circ} \mathrm{C}$ in an air circulation oven Marconi model MA 037 preserving its characteristic crunchiness and weight around $45 \mathrm{~g}$. They were then packed in pairs in polyethylene-aluminum-polyethylene (PVC/aluminum/PVC) films sealed under negative pressure using a packaging machine (R Baião Ind. Com. $\mathrm{Lt}^{\mathrm{d} a}$ ). Figure 1 shows the appearance of the cassava flour-based bars.

\subsection{Storage of bars}

The packed bars were stored under ambient conditions monitored using a smart meter (Geofoler). The packaged bars were placed in a rack under fluorescent light provided by three sets of lights with two lamps $(100 \mathrm{~V})$ each. During the experiment, the temperature ranged from $27^{\circ} \mathrm{C}$ to $30^{\circ} \mathrm{C}$ and relative humidity from a minimum of $27 \%$ to a maximum of $81 \%$.



Figure 1. Appearance of cassava flour-based bars packed in PVC/ aluminum/PVC) films.

\subsection{Physical and chemical analysis}

The shelf life study was conducted for 210 days, and the samples were tested every month. Packages were opened for analysis: 2 bars were used for microbial analysis, 2 bars were used for physicochemical analysis, and 15 bars were used for the sensory attributes. All analyses were performed with three replicates

Moisture content was obtained using an oven at $105^{\circ} \mathrm{C}$ with air circulation, according to Instituto Adolfo Lutz (INSTITUTO..., 2008). The bars were typically heterogeneous; therefore, an extract was obtained by crushing the sample in distilled water using a Taurus model 250 robot mixer. The extract was used for the physical and chemical analysis (INSTITUTO..., 2008). The $\mathrm{pH}$ was measured directly in the extract using a pH-Meter, acidity was measured based on $\mathrm{NaOH} 0.025 \mathrm{~N}$ using phenolphthalein as indicator and expressed as $\mathrm{NaOH}$ $\mathrm{N} / 100 \mathrm{~g}$ sample in $\mathrm{mL}$. Reducing sugars (RS) was measured by the Somogyi and Nelson (SOMOGYI, 1945; NELSON, 1944) method with an appropriate dilution, and absorbance readings were performed at $535 \mathrm{~mm}$. The non-reducing sugars were converted into reducing sugars using $\mathrm{HCl}$ (INSTITUTO..., 2008) and then measured as reducing sugars. Water activity (Aw) was measured using a portable Pawkit (Decagon).

\subsection{Microbial analysis}

The microbial count was measured on a daily basis for 210 days and included the total count of aerobic mesophilic (Nutrient Agar), yeasts and molds (Malt Extract), total and fecal coliforms (Eosin Methylene Blue Agar), and B. cereus, as described by Silva, Junqueira and Silveira (1997).

\subsection{Sensory analyses}

The evaluation of the sensory attributes was carried out in order to monitor stability, but without the intention to achieve market acceptance. 8 trained volunteer tasters, who signed a free and clear consent letter, conducted the sensory analysis. Sensory acceptability was evaluated based on the description of Aigster et al. (2011) for cereal bars using a 9-point hedonic 
scale for the following attributes: overall acceptance, color, form, texture, and chewiness. Texture was evaluated based on chewiness (number of chews necessary for swallowing).

\subsection{Evaluation of the nutritional value}

The nutritional value of the cassava flour-based bars was evaluated by a comparison with food composition tables such as that of Franco (2007).

\subsection{Statistical analysis}

The results were analyzed using the SYSTAT 12 software, and the means were compared using Tukey's multiple comparisons procedure at $p$-value $\leq 0.05$ as suggested by Aigster et al. (2011), for the analysis of cereal bars. The $\mathrm{r}^{2}$ (Pearson correlation coefficient) significance was indicated by an asterisk when $\mathrm{P} \leq 0.05$. The $\mathrm{r}^{2}$ was identified in the text using the abbreviation of the variable in brackets (RS, TRS, MA, etc...).

\section{Results and discussion}

The quality of a packed bar was determined by a 210-day analysis, and the results obtained are shown in Tables 1 to 3 . It can be said that it presents the profile expected for a quick meal.

The weight of the bars varied little due to the mechanical process used. The cassava flour-based bars as well as those mentioned by Loveday et al. (2009), when studying granola bars, were heterogeneous due to the presence of fruit and nut fragments and had the appearance of an aggregate of coarse particles This rough appearance adds value, characterizes the food bars, and may explain the variations in the results given the homogenization before the analysis.

Excessive weight loss may be due to the loss of moisture, but during the experiment the moisture values measured monthly were fairly consistent and proved that the multilayer film (PVC/ aluminum/PVC) has good barrier properties. This result is confirmed by the small variations in water activity $(\mathrm{Aw})$. These findings are better than those obtained by Aigster et al. (2011), who used multilayered flexible metalized packaging, which has been reported to have excellent oxygen barrier properties but less than ideal moisture barrier properties. The authors observed an increase in the water activity value of granola bars after 28 days of storage $\left(20^{\circ} \mathrm{C}\right)$.

The initial Aw of the cassava flour-based bars was 0.56. This value decreased during the first 90 days of storage, but the values did not differ statistically and continued to decrease during the entire storage period (210 days). The initial Aw of the cassava flour-based bars was lower than that reported by Aigster et al. (2011) (0.69) in granola bars, which significantly increased over the first week of storage up to the value of 0.77. A high initial value (0.65) was also found by Loveday et al. (2009) in protein bars during storage of 50 days at $20^{\circ} \mathrm{C}$. These results highlight the importance of using more mechanized processes and more appropriate films, such as those used with for cassava flour-based bars.
Table 1. Physical and chemical analysis of cassava flour-based bars stored under ambient conditions (average of three replicates).

\begin{tabular}{|c|c|c|c|c|c|c|c|}
\hline \multirow{2}{*}{ Days } & \multirow{2}{*}{$\begin{array}{c}\text { Mass } \\
(\mathrm{g})\end{array}$} & \multirow{2}{*}{$\begin{array}{c}\text { Moisture } \\
(\%)\end{array}$} & \multirow{2}{*}{$\begin{array}{l}\text { Aw } \\
(*)\end{array}$} & \multirow{2}{*}{$\frac{\text { T. Ac. }}{\left({ }^{* *}\right)}$} & \multirow{2}{*}{$\mathrm{pH}$} & \multicolumn{2}{|c|}{ Sugar (mg.100 g $\left.\mathrm{g}^{-1}\right)$} \\
\hline & & & & & & AR & ART \\
\hline 0 & $40.00^{\mathrm{a}}$ & $12.0^{\mathrm{b}}$ & $0.56^{\mathrm{a}}$ & $0.23^{c}$ & $5.60^{\mathrm{a}}$ & $230.62^{\mathrm{a}}$ & $307.15^{\mathrm{a}}$ \\
\hline 30 & $38.97^{\mathrm{a}}$ & $13.0^{\mathrm{a}}$ & $0.51^{\mathrm{b}}$ & $0.75^{\mathrm{a}}$ & $5.50^{\mathrm{a}}$ & $72.54^{\mathrm{b}}$ & $71.00^{\mathrm{b}}$ \\
\hline 60 & $39.80^{\mathrm{a}}$ & $12.0^{\mathrm{b}}$ & $0.50^{\mathrm{b}}$ & $0.36^{c}$ & $5.60^{\mathrm{a}}$ & $62.11^{\mathrm{b}}$ & $62.88^{\mathrm{b}}$ \\
\hline 90 & $30.88^{\mathrm{b}}$ & $10.4^{\mathrm{c}}$ & $0.51^{\mathrm{b}}$ & $0.72^{\mathrm{a}}$ & $5.50^{\mathrm{a}}$ & $35.44^{\mathrm{b}}$ & $38.32^{\mathrm{b}}$ \\
\hline 120 & $(* * *)$ & $9.79^{c}$ & $0.55^{\mathrm{a}}$ & $0.49^{\mathrm{b}}$ & $5.50^{\mathrm{a}}$ & $57.57^{\mathrm{b}}$ & $61.33^{\mathrm{b}}$ \\
\hline 150 & $(* * *)$ & $9.78^{c}$ & $0.54^{\mathrm{a}}$ & $0.34^{\mathrm{c}}$ & $5.50^{\mathrm{a}}$ & $47.00^{\mathrm{b}}$ & $47.20^{\mathrm{b}}$ \\
\hline 180 & $(* * *)$ & $10.04^{c}$ & $0.52^{\mathrm{b}}$ & $0.45^{\mathrm{b}}$ & $5.20^{\mathrm{b}}$ & $33.00^{\mathrm{b}}$ & $44.00^{\mathrm{b}}$ \\
\hline 210 & $(* * *)$ & $9.89^{c}$ & $0.52^{\mathrm{b}}$ & $0.48^{\mathrm{b}}$ & $5.50^{\mathrm{a}}$ & $37.00^{\mathrm{b}}$ & $33.00^{\mathrm{b}}$ \\
\hline$\sigma$ & 4,378 & 1,27 & 0,02 & 0,18 & 0,12 & 65,65 & 91,46 \\
\hline
\end{tabular}

$\left({ }^{*}\right)$ Water activity, $\left(^{* *}\right)$ : Titrable acidity expressed as $\mathrm{mL}$ of $\mathrm{NaOH} .100 \mathrm{~g}^{-1}$; $\left.{ }^{* * *}\right)$ samples lost by inadequate consistency. Means followed by lowercase letters in the same column are statistically different by the Tukey test at $\mathrm{p} \leq 0.05$.

Table 2. Microbial count expressed as colony forming units (CFU). $\mathrm{g}^{-1}$ of cassava flour-based bars stored under ambient conditions (average of three replicates).

\begin{tabular}{ccc}
\hline \multicolumn{3}{c}{ Count on $\left(\mathrm{CFU} \times 10^{2}\right) \cdot \mathrm{g}^{-1}$} \\
\hline Days & Aerobic mesophilic & Yeast and molds \\
\hline 0 & $54000.00^{\mathrm{a}}$ & $1.80^{\mathrm{b}}$ \\
30 & $29250.00^{\mathrm{b}}$ & $900.90^{\mathrm{a}}$ \\
60 & $53100.00^{\mathrm{a}}$ & $1800.00^{\mathrm{a}}$ \\
90 & $27.00^{\mathrm{c}}$ & No growth detected \\
120 & $14.90^{\mathrm{c}}$ & No growth detected \\
150 & $1.17^{\mathrm{c}}$ & No growth detected \\
180 & $0.68^{\mathrm{c}}$ & No growth detected \\
210 & No growth detected & No growth detected \\
\hline
\end{tabular}

Means followed by lowercase letters in the same column are statistically different by the Tukey test $(\mathrm{p} \leq 0.05)$

Table 3. Average values of sensory attributes for cassava flour-based bars at 0 and 30 days of storage under ambient temperature (evaluation by eight tasters).

\begin{tabular}{cccccc}
\hline Time & Color & Shape & Texture & Flavor & Chewiness ${ }^{(*)}$ \\
\hline 0 & $7.40^{\mathrm{a}}$ & $7.95^{\mathrm{a}}$ & $7.28^{\mathrm{a}}$ & $7.78^{\mathrm{a}}$ & $17.75^{\mathrm{a}}$ \\
30 & $7.34^{\mathrm{b}}$ & $7.06^{\mathrm{b}}$ & $7.52^{\mathrm{b}}$ & $8.14^{\mathrm{b}}$ & $15.00^{\mathrm{b}}$ \\
\hline
\end{tabular}

Means followed by lowercase letters in the same column are statistically different by the Tukey test at $\mathrm{p}$-value $\mathrm{P} \leq 0.05$; $\left(^{*}\right)$ number of chews.

Table 1 show that the weight and moisture of the bars remained stable up to 90 days and then decreased until the end of the experiment, but water activity (Aw) remained stable for a longer period of time. Aw was not significantly correlated with the moisture variation that occurred during storage (210 days), but the correlation was significant for the variation in reducing sugars $\left(\mathrm{RS} \mathrm{r}^{2} 0.609^{\star}\right.$ ) and in total reducing sugars ( $\mathrm{TRS} \mathrm{r}^{2} 0,627^{\star}$ ), which significantly decreased during storage $\left(\mathrm{r}^{2} \mathrm{RS}-0.700^{* *}\right.$; TRS $\mathrm{r}^{2}-0.663^{* *}$ ).

Based on these results, it was expected that the bars presented biological stability as stated by Azeredo, Brito and Garruti (2004) because the moisture content is not favorable to the growth of bacteria, yeasts, and molds. 
The increase in acidity is also a sign of either microbial activity or chemical reactions. The $\mathrm{pH}$ values decreased significantly $\left(\mathrm{pH} \mathrm{r}^{2}-0.585^{*}\right)$ during storage, but the same did not occur with acidity variation, which increased with the decrease in water activity $\left(\right.$ Aw $\left.\mathrm{r}^{2}-0.559^{*}\right)$. The results in Table 1 show that the acidity value reached the highest level of acidity $(0.72 \mathrm{~mL})$ after 90 days of storage, while the initial $\mathrm{pH}$ value (5.6) changed little.

The small difference between the total reducing sugar and reducing sugars shown in Table 1 is due to the influence of commercial glucose syrup (26\%) as the main source of sugar in the formula. The most common glucose syrup sold in Brazil has a DE (Dextrose Equivalent) of 42 to 48 , with $20 \%$ humidity, and its composition is mainly glucose $(34 \%)$, followed by maltose (15\%) and tetraose (15\%). The remaining $27 \%$ are composed of dextrin (more than seven glucose units) and $8 \%$ sugar (SUMERLY et al. 2003).

The variation in sugar content during storage for both reducing and total reducing sugars was significantly different. The total reducing sugars decreased during the entire storage period (Table 1). The reduction in sugar content was strongly influenced by the storage time and acidity. The content of both reducing sugars and total reducing sugars decreased significantly with time (RS $r^{2}-0.700^{* *}$; TRS $r^{2}-0.663^{* *}$ ). RS and TRS also influenced acidity although to a less pronounced degree (RS $r^{2}-0.513^{\star}$; TRS $\left.r^{2}-0.533^{\star}\right)$.

Unfortunately, the difference in composition between the bars reported by different authors (AIGSTER et al., 2011; LOVEDAY et al., 2009) make it difficult to understand sugar variations although it is suggested that the crystallization of glucose and retrogradation of starch molecules with the release of water as opposed to moisture migration through the material and packaging may partly explain the phenomenon.

Despite the variations, the sugar content may characterize the hydrolysis of complex sugars mainly present in glucose syrup, facilitated by the increasing of acidity for 90 days, resulting in reducing monomers (RS). Still, the decrease in the reducing sugar and total reducing sugar concentration during storage draws attention and points to the possibility of microbial activity.

Information on the microbial content of bars stored at ambient conditions was not found despite its importance in defining a safe food. Table 2 shows the microbial content of the bars analyzed expressed as colony-forming units $\left(\mathrm{CFU} \times 10^{2} \cdot \mathrm{g}^{-1}\right)$ during 210 days of storage. The material was screened for pathogens such as coliforms (total and fecal coliforms) and Bacillus cereus, but none were found. Such screening actually becomes irrelevant when considering the storage time.

Initially, the counts of aerobic mesophile were higher; there was an increased during the first 60 days, followed by a decrease until the end of the storage period. For yeasts and molds, the drop was sharp, and after 90 days of storage this group was no longer detected. After 180 days of storage, the counts of aerobic mesophiles that include yeasts and molds were performed. These results were consistent with the values of water activity and $\mathrm{pH}$ obtained in the same period. The drop in the aerobic count can be the attributed to the reduced oxygen remaining in the package.

Both the counts of aerobic mesophiles (MA) and those of molds and yeasts (MY) showed a significant reduction during storage and with Aw variation (MA $\mathrm{r}^{2}-0,571^{\star}$; MY $\left.\mathrm{r}^{2}-0,571^{\star}\right)$. The variations in the chemical and microbial evaluations were compared with the scores given by the testers to verify if they were able to perceive the effect of the changes due to storage time.

Santos et al. (2011) evaluated the sensory attributes overall acceptance, flavor, texture, and color of three formulas of cereal bars enriched with dehydrated jackfruit and the flour made with its dehydrated seeds and concluded that the three formulas were well accepted although texture was given lower scores for all formulas.

Changes in texture are mentioned in several food bar shelf life studies conducted by different authors. The bars can harden (LOVEDAY et al., 2009) or lose firm texture during storage.

Although analyses were conducted during the entire storage period (210 days), the sensory analysis ended after 30 days of storage (Table 3) due to ethical reasons. During handling, it was observed that the cassava flour-based bars were beginning to disintegrate inside the package; however, physicochemical and microbial test results indicate that the cassava flour-based bars are safe to be consumed as food.

Table 3 shows that the sensory attributes cannot be considered homogeneous when taking into account the opinions of all eight testers, but they indicate that changes occurred within the first 30 days of storage (changes that could be detected). In general, all scores became significantly worse.

Freitas and Moretti (2006) reported changes during the storage of cereal bars affecting the appearance, color, and overall acceptance, but they justify the darkening as an oxidative reaction due to the residual oxygen inside the package.

The analysis of the influence of storage time on cassava flour-based bars (Table 3) show that color, contrary to what was reported by Freitas and Moretti (2006), was maintained during the first 30 days of storage. The retention of the original color may be explained by the packaging film used (Figure 1) as well as air removal prior to sealing the package, which likely eliminated much of the residual oxygen.

At 30 days of storage, the shape attribute was significantly worse than that obtained initially, showing that the bars were losing their shape inside the package. Even so, the score for texture improved showing that the testers did not see such shape deformation as a negative factor. The evaluation of the texture attribute based on chewiness confirmed that the bars were softer, resulting in higher scores. This softening at 30 days of storage was the first sign of bar disintegration. It was possible to successfully re-shape or restructure the broken bars by adding more water or commercial glucose syrup as a binder and recompressing the mixture. 
Finally, flavor was not negatively affected by the storage time, and in fact it even showed increased scores for the period evaluated.

The shelf life analyses show that the quality of cassava flourbased bars was quite stable, and the product may be considered safe, but it is also important to determine its nutritional value. When the amount of each ingredient used in the formula is compared with that on the table of food composition (FRANCO, 2007), it is possible to estimate the nutritional value of a $45 \mathrm{~g}$ bar as $2.2 \mathrm{~g}$ moisture, $30.0 \mathrm{~g}$ carbohydrate, $6.5 \mathrm{~g}$ protein, $4.8 \mathrm{~g}$ fat, and $1.5 \mathrm{~g}$ dietary fiber. This calculation considers a formula for the production of twelve bars of $45 \mathrm{~g}$ each and $186.0 \mathrm{kcal}$ or 4 kcal.g-1.

The results showed that by simply mixing it with select ingredients and pressing the mixture into bars in order to provide a practical, modern and attractive food, nutritionally improved the cassava flour. Thus, the bars produced have a lower caloric value than that of commercial bars evaluated in previous studies. Aigster et al. (2011) reports finding granola bars with $380 \mathrm{kcal}$.

According to Aprile (2011), gym-goers usually consume energy bars $(25 \mathrm{~g})$ with nearly $250 \mathrm{kcal}\left(10 \mathrm{kcal}^{-1} \mathrm{~g}^{-1}\right)$, a greater amount of calories than that of a common cereal bar.

The bar made with cassava flour enriched with nuts and dried fruits can be considered as an intermediate bar between those reported by Aprile (2011) as common cereal bars (100 calories) and energy bars (250 to $280 \mathrm{kcal})$.

Grden, Oliveira and Bortolozo (2008) developed cereal bars in order to meet the nutritional needs for physically active people and athletes. They also included important ingredients for the target consumer, such as whey and maltdextrin because athletes need a greater amount of energy, depending on the individual and the activity to be performed. The bars with $50 \mathrm{~g}$ provided a caloric value of $231 \mathrm{kcal}$ with $31 \mathrm{~g}$ carbohydrates, $6 \mathrm{~g}$ protein, $10 \mathrm{~g}$ of fat, and 2.5 grams of fiber.

If the probable composition of cassava flour-based bars is compared with that reported in the literature, it is possible to confirm that now they are more compatible with the fast food profile. The use of dehydrated banana is a good source of potassium, a micronutrient that is very important in practical exercise. When it comes to nut selection, ground cashew nuts are not considered as relevant, but it is possible to add value to local nuts just as with peanuts, or even the regional nut named "baru" (Dpyteryx alata Vog.), native of the Central West Brazilian region. The nuts also provide polyunsaturated fats that are considered as functional foods and that when consumed properly may prevent diseases. This ingredient can be varied and measured in order to increase or decrease the caloric value of the bars in order to meet the specific needs of the consumer.

Grden, Oliveira and Bortolozo (2008) report that the slightly higher fat content in a bar may be important to replenish the energy used during physical activities due to the depletion of energy stores during exercise.

In the proposed formula, the lipid content represents about $11 \%$ of each cassava flour-based bar. The lipid content mainly comes from the hydrogenated fat, but it also comes from cashew nuts.

Freitas and Moretti (2006) analyzed cereal bars produced using different ingredients and found that all bars had lower fat content. The formula with wheat germ presented $10.57 \%$ lipids. This value is relatively close to that found in the cassava flour-based bars.

The value of $1.53 \mathrm{~g}$ of fiber calculated for each unit of $45 \mathrm{~g}$ of cassava bar may represent $6.12 \%$ of the recommended daily intake. Grden, Oliveira and Bortolozo (2008) point out that the fibers may help starch hydrolysis and, therefore aid digestion. The same authors (GRDEN; OLIVEIRA; BORTOLOZO, 2008) report that cereal bars with a high protein content are considered a source of protein which meet the needs of approximately $16 \%$ of moderately active practitioners, whereas the protein needs of an individual athlete are larger than those of sedentary people (JUZWIAK; PASCHOAL; LOPEZ, 2000).

The protein content calculated for cassava flour-based bars may be considered higher than those found by Grden, Oliveira and Bortolozo (2008), and correspond to $14.5 \%$ of the required daily intake.

Finally, the carbohydrate content of a bar using the selected formula may be calculated as $29 \mathrm{~g}$ and represents $64.4 \%$ of the daily needs of consumers. The high carbohydrate content is important as a source of quick energy if this energy comes from simple carbohydrates, or slow if it comes from complex ones (DEGASPARI; BLINDER; MOTTIN, 2008).

Despite their potential as a food that suits modern nutritional needs, it is necessary to improve the stability of the bars. The results obtained did not point to the microbial activity as the of cause the loss of texture at the end of the 210 days, but they seem to indicate that in addition to the chemical modifications, there was moisture migration between the raw materials used, mainly between the fruit and cassava flour, resulting in a reduction of the ligand effect of glucose and water. The results of reducing sugars and total reducing sugars also suggest that hydrolysis of the glucose syrup occurred as well, with a reduction of chain size and increased reducing terminal.

The aforementioned reasons agree with those of Loveday et al. (2009), who suggested that chemical reactions have only a small role in the changes in molecular mobility, and changes in microstructure driven by moisture migration may be more significant.

\section{Conclusion}

The cassava flour-based formula enriched with ingredients provided nutritionally balanced $45 \mathrm{~g}$ bars that presented physical, chemical, and microbial stability for 90 days when packed in vacuum sealed polyethylene film Polyester PET/AL/ $\mathrm{PE}$ stored under ambient conditions in an artificially illuminated room. As for the nutritional value of the bars, they can be considered as a well-balanced fast food.

\section{Acknowledgements}

The authors are grateful for the financial support provided by PIBIC/CNPq Program. 


\section{References}

AIGSTER, A. et al. Physicochemical properties and sensory attributes of resistant starch-supplemented granola bars and cereals. LWT Food Science and Technology, v. 44, n. 10, p. 2159-2165, 2011.

APRILE, J. Barras que valem ouro. Viva Saúde online, n. 35, 2006. Disponível em: <http://revistavivasaude.uol.com.br/edicoes/35/ artigo35776-1.asp>. Acesso em: 01 jun. 2011.

AZEREDO, H. M. C.; BRITO, E. S.; GARRUTI, D. S. Alterações químicas durante a estocagem. In: AZEREDO, H. M. C. Fundamentos de estabilidade de alimentos. Fortaleza: Embrapa Agroindústria Tropical, 2004. p. 37-59.

BRITO, I. P. et al. Elaboração e avaliação global de barra de cereais caseira. Boletim do CEPPA, v. 22, n. 1, p. 35-50, 2004.

BRITO, S. R. Barras Energéticas. Disponível em: <http://www. adventuremag.com.br/dicas/EpAFypullkcnHOQoFr.php $>$. Acesso em: 15 maio 2005.

CASTRO-ANTUNES, M. M. et al. Doença celíaca em familiares de primeiro grau de portadores. Journal of Pediatrics, v. 6, n. 4, 2010.

CEREDA, M. P. Caracterização dos subprodutos da industrialização da mandioca. Caracterização dos subprodutos da industrialização da mandioca. In: CEREDA, M. P. Manejo, uso e tratamento de subprodutos da industrialização da mandioca. São Paulo: Fundação Cargill, 2001. v. 4, cap. 1, p. 13-47.

CEREDA, M. P.; VILPOUX, O. F. Farinhas e Derivados. In: CEREDA. M. P.; VIOPOUX. O. F. Tecnologias, usos e potencialidades de tuberosas amiláceas latino americanas. São Paulo: Fundação Cargill, 2003. v. 3, cap. 20, p. 577-621.

DEGASPARI, C. H.; BLINDER, E. W.; MOTTIN, F. Perfil nutricional do consumidor de barras de cereais. Visão Acadêmica, v. 9, n. 1, p. 49-61, 2008.

DUARTE, R. Comendo bem. Disponível em: <http://comendobem. wordpress.com/2008/05/01/produtos-derivados-da-mandioca/ $>$. Acesso em: 30 jun. 2008.

DUTCOSKY, S. D. et al. Combined sensory optimization of a prebiotic cereal product using multicomponent mixture experiments. Food Chemistry, v. 98, p. 630-638, 2006. http://dx.doi.org/10.1016/j. foodchem.2005.06.029

FRANCO, G. Tabela de composição química dos alimentos. 9. ed. São Paulo: Atheneu, 2007. 307 p.

FREITAS, D. G. C.; MORETTI, R. H. Caracterização e avaliação sensorial de barra de cereais funcional de alto teor protéico e vitamínico. Ciência e Tecnologia de Alimentos, v. 26, n. 2, p. 318-324, 2006. http://dx.doi.org/10.1590/S0101-20612006000200014

GOMES, A. T.; CEREDA, M. P.; VILPOUX, O. Desidratação Osmótica: uma tecnologia de baixo custo para o desenvolvimento da agricultura familiar. Revista Brasileira de Gestão e Desenvolvimento Regional, v. 3, n. 3, p. 212-226, 2007.

GOMES, F. O. et al. Avaliação sensorial de barra de cereais produzidas parcialmente com albedo de maracujá amarelo Passiflora edulis. In: SIMPOSIO DE PRODUTIVIDADE EM PESQUISA, 2.; ENCONTRO DE INICIAÇÃO CIENTIFICA DO IFPI, 2., 2009, Piauí. Anais... Cidade Nova: IFPI, 2009.

GRDEN, L.; OLIVEIRA, C. S.; BORTOLOZO, E. A. F. Q. Elaboração de uma barra de cereais como alimento compensador para praticantes de atividade física e atletas. Revista Brasileira de Tecnologia Agroindustrial, v. 2, n. 1, p. 87-94, 2008. http://dx.doi.org/10.3895/ S1981-36862008000100008

GRIZOTTO, R. K. Estudo da vida-de-prateleira de fruta estruturada e desidratada obtida de polpa concentrada de mamão. Ciência e
Tecnologia de Alimentos, v. 26, n. 3, p. 709-714, 2006. http://dx.doi. org/10.1590/S0101-20612006000300035

GUTKOSKI, L. C.; Desenvolvimento de barras de cereais à base de aveia com alto teor de fibra alimentar. Ciência e Tecnologia de Alimentos, v. 27, n. 2, p. 355-363, 2007. http://dx.doi.org/10.1590/ S0101-20612007000200025

INSTITUTOBRASILEIRO DEGEOGRAFIA EESTATÍSTICAS - IBGE. Pesquisa de Orçamento Familiar - POF, 2010. Rio de Janeiro: IBGE, 2010. Disponível em: <http://www.ibge.gov.br/home/ presidencia/noticias/noticia_impressao.php?id_noticia $=1788>$. Acesso em: 04 mar. 2011.

INSTITUTO ADOLFO LUTZ - IAL. Métodos físico-químicos para análise de alimentos. Brasília: Anvisa, 2008.

JUZWIAK, C. R.; PASCHOAL, V. C. P.; LOPEZ, F. A. Nutrição e atividade física. Journal of Pediatrics, v. 76, 2000. Suplemento 3.

LEONEL, M.; CEREDA, M. P.; ROAU, X. Aproveitamento do resíduo da produção de etanol a partir de farelo de mandioca como fonte de fibras dietéticas. Ciência e Tecnologia de Alimentos, v. 19 , n. 2, p. 241-245, 1999. http://dx.doi.org/10.1590/S010120611999000200016

LOVEDAY, S. M. et al. Physicochemical changes in a model protein bar during storage. Food Research International, v. 42, n. 7, p. 798-806, 2009. http://dx.doi.org/10.1016/j.foodres.2009.03.002

MAHANNA, K.; MOSKOWITZ, H. R.; LEE, S.-Y. Assessing consumer expectations for food bars by conjoint analysis. Journal of Sensory Studies, v. 24, p. 851-870, 2009. http://dx.doi.org/10.1111/j.1745459X.2009.00241.X

NELSON, N. A. Photometric adaptation of the Somogy method for the determination of glucose. The Journal of Biological Chemistry, n. 153, p. 375-380, 1944.

PEHANICH, M. No holds barred. Prepared foods, v. 172, n. 3, p. 79-80, 2003.

RYLAND, D. et al. Development of a nutritious acceptable snack bar using micronized flaked lentils. Food Research International, v. 43, p. 642-649, 2010. http://dx.doi.org/10.1016/j.foodres.2009.07.032

SANTOS, C. T. et al. Characterization and sensorial evaluation of cereal bars with jackfruit. Acta Scientiarum Technology, v. 33, n. 1, p. 81-85, 2011.

SDEPANIAN, V. L.; MORAIS, M. B.; FAGUNDES-NETO, U. Doença celíaca: características clínicas e métodos utilizados no diagnóstico de pacientes cadastrados na Associação dos Celíacos do Brasil. Journal of Pediatrics, v. 77, n. 2, p. 131-138, 2001. http://dx.doi. org/10.2223/JPED.189

SILVA, N.; JUNQUEIRA, V. C. A.; SILVEIRA, N. F. A. Manual de métodos de análise microbiológica de alimentos. 2. ed. São Paulo: Livraria Varela, 2001. 156 p.

SOMOGYI, M. Determination of blood sugar. The Journal of Biological Chemistry, Baltimore, n. 160, p. 69-73, 1945.

SOUZA, J. M. L. et al. Caracterização físico-química de farinhas oriundas de variedades de mandioca utilizadas no vale do Juruá, Acre. Acta Amazonica, v. 38, n. 4, p. 761-766, 2008. http://dx.doi. org/10.1590/S0044-59672008000400021

SUMERLY, R. et al. Hidrólise do amido. In: CEREDA, M.; VILPOUX, O. Tecnologia, usos e potencialidades de tuberosas Latino Americanas. São Paulo: Fundação Cargil, 2003. v. 3, cap. 15, p. 377-448.

WRIGHT, R. C. et al. Alterações microbiológicas durante a estocagem. In: AZEREDO, H. M. C. Fundamentos de Estabilidade de Alimentos. Fortaleza: Editora Técnica, 2004. p. 19-33. PMid:17129299. 